\title{
PENGARUH UNIT SIMPAN PINJAM TERHADAP PENINGKATAN KESEJAHTERAAN EKONOMI MASYARAKAT DESA
}

\author{
Eka Kusuma Ramadani, Dewi Oktayani \\ Sekolah Tinggi Ilmu Ekonomi (STIE) Syariah Bengkalis \\ ekakusumarmd@yahoo.com, dewioktayani87@gmail.com \\ https://doi.org/10.46367/jps.v1i2.230
}

Received: Jul 29, 2020 Revised: Sep 18, 2020 Accepted: Sep 29, 2020 Published: Oct 12, 2020

\begin{abstract}
This research aims to analyze and provide empirical evidence regarding the effect of the Penebal Teguh Mandiri savings and loan unit on improving the economic welfare of the Penebal village community. The problem in this research is that many people still use savings and loan units towards consumptive use. The data analysis method used is a quantitative analysis using validity and reliability tests, simple linear regression analysis, classical assumption test and the coefficient of determination using SPSS. The population used is the Penebal Village community with the criteria being the people who make loans at the Penebal Teguh Mandiri office of Penebal Village. The sample used was 174 people from the Penebal Village community. The results of this research indicate that only $38 \%$ of the level of influence of the savings and loan unit on the level of the economic welfare of the Penebal village community.
\end{abstract}

Keywords: Savings and Loans, Level of Welfare, Village Community Economy.

\begin{abstract}
ABSTRAK
Penelitian ini bertujuan untuk menganalisis dan memberikan bukti empiris mengenai pengaruh unit simpan pinjam Penebal Teguh Mandiri terhadap peningkatan kesejahteraan ekonomi masyarakat desa Penebal. Adapun permasalahan yang terdapat dalam penelitian ini adalah masih banyak masyarakat menggunakan dana unit simpan pinjam kearah konsumtif. Metode analisis data yang digunakan adalah analisis kuantitatif dengan menggunakan uji validitas dan uji reliabilitas, analisis regresi linier sederhana, uji asumsi klasik dan koefisien determinasi dengan menggunakan SPSS. Populasi yang digunakan adalah masyarakat Desa Penebal dengan kriteria merupakan masyarakat yang melakukan peminjaman di kantor USP Penebal Teguh Mandiri Desa Penebal. Sampel yang digunakan sebanyak 174 orang terhadap masyarakat Desa Penebal. Hasil dari penelitian ini menunjukan bahwa hanya $38 \%$ tingkat pengaruh unit simpan pinjam terhadap tingkat kesejahteraan ekonomi masyarakat desa Penebal.
\end{abstract}

Kata Kunci: Simpan Pinjam, Tingkat Kesejahteraan, Ekonomi Masyarakat Desa.

\section{PENDAHULUAN}

Hakikat pembangunan adalah upaya mewujudkan kesejahteraan masyarakat. Hal tersebut diperjelas dalam pembukaan UUD 1945 bahwa tujuan 
kemerdekaan yaitu memajukan kesejahteraan umum dan mencerdaskan kehidupan bangsa. Dengan demikian pembangunan nasional diharapkan mampu menuju pada keseimbangan, keserasian, dan keselarasan dalam kehidupan masyarakat (Sudjana 2004, 148).

Penanggulangan kemiskinan dengan menitikberatkan pada pemberdayaan masyarakat sebagai pendekatan operasional, merupakan wujud komitmen pemerintah dalam merealisasikan kesejahteraan sosial bagi masyarakat. Program Pemberdayaan Desa (PPD) merupakan wujud nyata dari penanggulangan kemiskinan di Provinsi Riau. Didalam peraturan Gubernur Riau No 15 Tahun 2006 Tentang Pedoman Umum dan Petunjuk Teknis Program Pemberdayaan Desa Provinsi Riau menjelaskan bahwa seluruh proses kegiatan dalam PPD pada hakikatnya memiliki 3 (Tiga) dimensi yaitu: (1) Memberi wewenang dan kepercayaan kepada masyarakat untuk menentukan sendiri kebutuhannya, merencanakan kegiatan pembangunan, melaksanakan secara terbuka dan penuh tanggung jawab. (2) Memberikan dukungan bagi terciptanya lingkungan yang kondusif untuk mewujudkan peran masyarakat dalam pembangunan, khususnya dalam upaya peningkatan kesejahteraan mereka sendiri. (3) Menyediakan dana usaha desa untuk mendanai kegiatan ekonomi masyarakat desa.

Arah kebijakan Program Pemberdayaan Desa adalah mempercepat penanggulangan kemiskinan melalui pengembangan ekonomi masyarakat dengan pemberian dana Unit Simpan Pinjam (USP) menuju kemandirian masyarakat desa. Pemberdayaan masyarakat merupakan suatu upaya untuk meningkatkan kemampuan masyarakat agar mampu mewujudkan kemandirian dan melepaskan diri dari belenggu kemiskinan serta keterbelakangan (Kurniawati et al. 2013, 9).

Sebagai sebuah Negara yang besar, Indonesia memiliki ribuan desa yang tersebar di 33 provinsi dan di Riau sendiri terdapat 8 kecamatan yang terdiri dari kecamatan Mandau, Pinggir, Bukit Batu, Siak Kecil, Rupat, Rupat Utara, Bengkalis dan Bantan. Sedangkan desa dipesisirnya berjumlah 53 dan desa bukan dipesisir berjumlah 49 Desa (BPS Kabupaten Bengkalis 2018). Untuk mengembangkan desa-desa tersebut dibuatlah program pemberdayaan desa. Program pemberdayaan desa tahun 2005 merupakan tahapan pilot projeck (proyek percobaan) dari program pemerintah. Oleh sebab itu, kehati-hatian dalam menentukan desa sebagai sasaran program menjadi bahan pertimbangan yang sangat penting agar tercapai tujuan secara maksimal. Sebagian warga masyarakat berada dalam lingkaran kemiskinan, maka perlu adanya kebijakan dan program untuk menunjang masyarakat agar sejahtera dari segi sosialnya.

Definisi ini menekankan bahwa kesejahteraan masyarakat adalah suatu institusi atau bidang kegiatan yang melibatkan aktivitas terorganisir yang diselenggarakan baik oleh lembaga-lembaga pemerintah maupun swasta yang bertujuan untuk mencegah, mengatasi atau memberikan kontribusi terhadap pemecahan masalah masyarakat, peningkatan kualitas hidup individu, kelompok dan sosial. Pengembangan masyarakat ialah proses tujuan untuk menciptakan kemajuan sosial dan ekonomi masyarakat melalui partisipasi aktif serta inisiatif anggota masyarakat itu sendiri.

Penelitian yang membahas mengenai Unit simpan pinjam menurut permendagri No.06 tahun 1998 adalah suatu lembaga yang bergerak dibidang simpan pinjam dan merupakan milik masyarakat desa keseluruhan yang diusahakan serta dikelola masyarakat desa/kelurahan. Badan usaha milik desa 
adalah semua usaha ekonomi yang diusahakan oleh masyarakat desa/kelurahan dan untu masyarakat desa/kelurahan baik secara perorangan atau secara kelompok (koperatif) (Prasetyo 2018).

Unit Simpan Pinjam (USP) memberikan kemudahan bagi masyarakat desa untuk mendapatkan modal melalui kredit yang mudah, murah, suku bunga yang rendah untuk meningkatkan dan mengembangkan usahanya serta yang paling diharapkan adalah meningkatkan pendapatan agar kesejahteraan masyarakat desa lebih terjamin.

Dalam usaha pemerintah untuk mengurangi tingkat kemiskinan yang ada diperdesaan, sebagian ada yang berhasil mengelola dengan baik sehingga banyaknya usaha-usaha yang bermunculan dan menumbuhkan minat berusaha dari masyarakat, dan ada juga sebagian dari pengelola Unit Simpan Pinjam (USP) yang kesulitan dalam hal mengelola lembaga simpan pinjam tersebut lantaran banyaknya masyarakat yang menggunakan dana tersebut kearah komsumtif, sehingga program pemerintah yang memang memfokuskan pendanaan tersebut untuk usaha-usaha produktif tidak tepat sasaran didalam pelaksanaannya.

Pemberdayaan adalah bagian dari paradigma pembangunan yang memfokuskan perhatiannya pada semua aspek yang prinsipil dari manusia dilingkungannya, yakni mulai dari aspek intelektual (sumber daya manusia), aspek material dan fisik, sampai kepada aspek manajerial. Aspek-aspek tersebut bisa jadi dikembangkan menjadi aspek sosial-budaya,ekonomi, politik, keamanan, dan lingkungan (Londa 2014).

Unit Simpan Pinjam (USP) diharapkan mempunyai peran tersendiri dalam menjadi pemecahan masalah dan membenahi masyarakat desa dalam mendapatkan tambahan modal yang mereka butuhkan melalui kredit yang terjangkau dan prosedur yang sederhana. Dengan tambahan modal yang diberikan, usaha masyarakat desa akan semakin meningkat dan berkembang dengan ketersediaan modal yang bertambah, dan diharapakan pendapatan masyarakat desa akan semakin meningkat. Selain itu juga Unit Simpan Pinjam (USP) diharapkan dapat membantu masyarakat kecil/miskin dalam upaya untuk mendapatkan modal usaha dengan persyaratan yang mudah, murah dan cepat sehingga hasilnya secara nyata dapat memberikan peningkatan taraf hidup dan kesejahteraan masyarakat sesuai dengan tujuan Unit Simpan Pinjam (USP) tersebut.

Adapun tujuan penelitian ini adalah untuk mengetahui bagaimana bentuk transaksi Unit Simpan Pinjam (USP) Penebal Teguh Mandiri Desa Penebal. Kemudian untuk mengetahui pengaruh Unit Simpan Pinjam (USP) terhadap peningkatan kesejahteraan ekonomi masyarakat desa Penebal.

\section{TELAAH LITERATUR}

\section{Unit Simpan Pinjam (USP)}

Dalam Undang-undang No.3 Tahun 1982 tentang wajib daftar perusahaan, usaha adalah setiap tindakan, perbuatan, atau kegiatan apapun dalam bidang perekonomian yang dilakukan oleh setiap pengusaha atau individu untuk tujuan memperoleh keuntungan atau laba (Solihin 2006, 27). 
Tujuan Usaha terdiri dari: (1) Untuk memenuhi kebutuhan hidup, (2) Untuk kemaslahatan keluarga, (3) Usaha untuk bekerja (Kasmir dan Jakfar 2003). Adapun dalil tentang usaha didalam surat At-Taubah ayat 105:

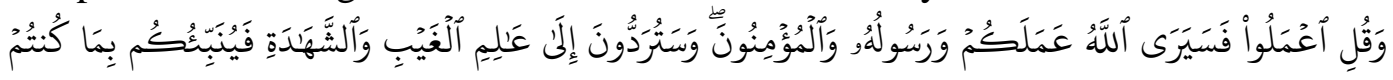

Artinya: dan Katakanlah: "Bekerjalah kamu, Maka Allah dan Rasul-Nya serta orang-orang mukmin akan melihat pekerjaanmu itu, dan kamu akan dikembalikan kepada (Allah) yang mengetahui akan yang ghaib dan yangnyata, lalu diberitakan-Nya kepada kamu apa yang telah kamu kerjakan.

Koperasi simpan pinjam atau koperasi kredit adalah yang bergerak dalam lapangan usaha pembentukan modal melalui tabungan-tabungan para anggotanya dengan cara yang mudah, murah, cepat dan tepat untuk tujuan produktivitas dan kesejahteraan (Nurhanafi 2014, 2). Unit simpan pinjam (USP) adalah salah satu program pemberdayaan desa yang bergerak dibidang keuangan untuk menunjang usaha ekonomi produktif didesa yang bersangkutan. Usaha ekonomi produktif ini meliputi seluruh kegiatan usaha baik perorangan ataupun kelompok yang merupakan parakarsa dari masyarakat sendiri untuk meningkatkan taraf hidupnya, antara lain: (a) Perdagangan, kios, warung. (b) Pertanian, tanaman pangan. (c) Perkebunan, sawit, karet, kelapa. (d) Jasa, perbengkelan. (e) Industri. (f) Perikanan.

Kredit USP adalah pinjaman yang diberikan oleh USP kepada pihak peminjam untuk membiaya usaha tertentu dengan jumlah tertentu dan jangka waktu tertentu, dan pihak peminjam wajib mengembalikan pinjamannya berserta bunga atau jasa pinjaman. Unsur-unsur kredit terdiri dari: kepercayaan, waktu, resiko, kesepakatan, penyerahan. Dalam memberikan pinjaman pada unit simpan pinjam menggunakan prinsip $5 \mathrm{C}$ yaitu: Character (Kepribadian), Capacity (Kemampuan), Capital (Modal), Condition of economy (Kondisi Ekonomi) dan Collateral (Agunan).

Adapun tujuan dibentuknya unit simpan pinjam adalah: (1) Mendorong kegiatan perekonomian masyarakat Desa/Kelurahan. (2) Meningkatkan kreativitas berwirausaha anggota masyarakat Desa/Kelurahan yang berpenghasilan rendah. (3) Mendorong usaha sektor informasi untuk penerapan tenaga kerja bagi masyarakat Desa/Kelurahan. (4) Menghindarkan anggota masyarakat Desa/Kelurahan dari Pengaruh pelepasan uang dengan bunga tinggi yang bisa merugikan masyarakat. (5) Meningkatkan peranan masyarakat Desa/Kelurahan dalam rangka menampung dan mengelola bantuan modal yang berasal dari pemerintah atau sumber-sumber lain yang sah. (6) Memelihara dan meningkatkan adat kebiasaan dan gotong royong untuk gemar menabung secara tertib teratur bermanfaat dan berkelanjutan.

Sasaran kegiatan unit simpan pinjam adalah masyarakat yang berada di Desa/Kelurahan baik perorangan maupun kelompok yang akan memulai berusaha atau mengembangkan usahanya. Adapun kegiatan yang dilakukan Unit Simpan Pinjam (USP) adalah: (1) Memberikan pinjaman uang untuk kegiatan usaha masyaraka Desa/Kelurahan yang dinilai produktif. (2) Menerima pinjaman uang dari masyarakat Desa/Kelurahan sebagai anggota USP. (3) Ikut serta memberikan bimbingan dan penyuluhan kepada anggota USP dalam kaitan usahanya. (4) 
Melaksanakan koordinasi dengan lembaga perbankan/perkreditan lainya dalam pelaksanaan simpan pinjam.

\section{Kesejahteraan Ekonomi}

Peningkatan adalah proses atau cara untuk meningkatkan usaha (Depdikbud 1988, 951). Jadi, peningkatan merupakan suatu proses yang dimana proses tersebut memberikan hasil tersebut usaha yang dilakukan seseorang menjadi lebih meningkat. Sedangkan kesejahteraan adalah keamanan, keselamatan, ketentraman, kesenangan hidup, dan kemakmuran (Depdikbud 1988, 62). Sejahtera menuju pada keadaan yang baik, kondisi manusia dimana orangorangnya dalam keadaan makmur, dalam keadaan sehat dan damai.

Ekonomi sebagaimana yang diketahui secara umum adalah suatu benda yang menjadi kebutuhan seseorang. Sedangkan untuk mendapatkan hal tersebut, yaitu dengan cara melakukan kegiatan untuk memanfaatkan dan mempergunakan unsur-unsur produksi dengan sebaik-baiknya. Dengan tujuan memenuhi berbagai rupa kebutuhan ekonomi atau benda (Anshori 1993, 67). Jadi, peningkatan Kesejahteraan Ekonomi Adalah suatu usaha yang dilakukan oleh masyarakat untuk mendapatkan keuntungan benda dalam melakukan pemenuhan kebutuhannya. Tingkat kesejahteraan masyarakat dapat diukur dari tingkat pendapatan dan sisi kebutuhan terpenuhi.

Masyarakat yang meminjam modal dari USP sangat membantu perekonomiannya apalagi dari segi pendapatan. Karena, sebelum masyarakat meminjam modal dari USP pendapatannya sekitar $1.000 .000,-$ perbulan, tetapi sekarang sudah mencapai 2.000.000,- sampai 3.000.000,- perbulan dengan membuat usaha dari pinjaman modal USP tersebut. Kemudian dari sisi terpenuhi kebutuhan, ada sebagian masyarakat yang mengatakan bahwa dengan adanya USP ini sangat membantu kebutuhannya. Contohnya dari segi pembangunan, masyarakat yang memiliki usaha yang dulunya kecil dengan adanya modal dari USP sekarang usahanya sudah besar.

Ekonomi Islam yang merupakan salah satu bagian dari Syariat Islam, tujuannya tentu tidak lepas dari tujuan utama Syariat Islam. Tujuan utama ekonomi islam adalah merealisasikan tujuan manusia untuk mencapai kebahagiaan dunia dan akhirat. Serta kehidupan baik dan terhormat (Nailufarh 2010). Ini merupakan definisi kesejahteraan dalam pandangan islam, yang tentu saja berbeda secara mendasar dengan pengertian kesejahteraan dalam ekonomi konvensional yang sekuler dan materialistik.

Secara terperinci, tujuan ekonomi islam dapat dijelaskan sebagai berikut: (1) Kesejahteraan ekonomi adalah tujuan ekonomi yang terpenting. Kesejahteraan ini mencakup kesejahteraan individu, masyarakat dan Negara. (2) Tercukupinya kebutuhan dasar manusia, meliputi makan, minum, pakaian, tempat tinggal, kesehatan, pendidikan, keamanan serta sistem Negara yang menjamin terlaksananya kecukupan kebutuhan dasar secara adil dibidang ekonomi. (3) Penggunaan berdaya secara optimal, efisien, efektif, hemat dan tidak mubazir. (4) Distribusi harta, kekayaan, pendapatan dan hasil pembangunan secara adil dan merata. (4) Menjamin kebebasan individu. (5) Kesamaan hak dan peluang. (6) Kerjasama dan keadilan.

Sehubungan dengan usaha penciptaan kesejahteraan ekonomi rakyat tersebut, agenda pemerintah yang telah ditetapkan tersebut merupakan agenda 
untuk meningkatkan kesejahteraan ekonomi rakyat, dimana agenda ini diarahkan pada pencapaian lima sasaran pokok, yaitu: (1) Pengurangan kemiskinan dan pengangguran. (2) Berkurangnya kesenjangan antar wilayah. (3) Meningkatkan kualitas manusia. (4) Membaiknya mutu lingkungan hidup. (5) Meningkatnya dukungan infrastruktur.

Sedangkan terdapat juga agenda kinerja pemerintah dalam bidang kesejahteraan ekonomi rakyat yang diuraikan dalam delapan bidang, yaitu: (1) Penanggulangan kemiskinan dan kesejahteraan sosial. (2) Ekonomi. (3) Pembangunan daerah. (4) Sumber daya manusia. (5) Agama. (6) Sumber daya alam dan lingkungan hidup. (7) Infrastruktur (8) Penanggulangan pasca bencana alam.

Dilihat dari segi realita saat ini, agenda tersebut sebagian besar tidak dapat dijalankan dengan benar, justru semakin membuat masyarakat kecil mengalami kesenjangan hidup yang semakin meningkat dalam hal perekonomian yang semakin sulit, ditambah lagi dengan berbagai macam persoalan perekonomian Negara, mulai dari permasalahan kenaikan harga BBM, krisis energi, krisis pangan yang mengakibatkan kenaikan harga barang kebutuhan pokok dan lain sebagainya.

Kesejahteraan ekonomi sangat sulit dicapai bila keadaan perekonomian tidak semakin membaik, dan masalah ekonomi dianggap wilayah kecil yang merupakan bagian dari wilayah besar masyarakat. Dengan perkembangan masyarakat yang makin komplek, kehidupan ekonomi menjadi makin penting dan lama kelamaan dalam sistem ekonomi kapitalisme seakan-akan menjadi jauh lebih penting dari pada masyarakat sendiri. Masyarakat Indonesia telah menyadari bahwa krisis yang dihadapi sejak 1997 merupakan krisis multidimensi (politik, ekonomi, budaya), namun orang cenderung dengan mudah menyebutnya sebagai krisis ekonomi.

Pembangunan ekonomi sangat penting bagi kesejahteraan. Secara global dan khususnya di Negara-negara industri maju, prtumbuhan ekonomi telah memperkuat integrasi dan solidaritas sosial, serta memperluas kemampuan dan akses orang terhadap pelayanan kesehatan, pendidikan tempat tinggal, dan perlindungan sosial.

Kebijakan privatisasi, pasar bebas dan penyesuaian struktural yang ditekankan lembaga-lembaga internasional telah mendorong Negara-negara berkembang kedalam situasi dimana populasi miskin mereka hidup tanpa perlindungan. Meskipun pertumbuhan ekonomi penting, tetapi ia tidak secara otomatis melindungi rakyat dari berbagai resiko yang mengancamnya. Oleh karena itu, beberapa Negara berkembang mulai menerapkan kebijakan sosial yang menyangkut pengorganisasian skema-skema jaminan sosial, meskipun masih terbatas dan dikaitkan dengan status dan kategori pekerja disektor formal.

Indonesia bisa saja menciptakan kesejahteraan ekonomi, namun hal tersebut tidak akan lepas dari keberadaan dan peran pemerintah, dan berbagai pihak yang memiliki kepentingan lain dari keberadaan perekonomian Indonesia saat ini. Dengan adanya permasalahan kenaikan harga BBM, pengurangan subsidi, adanya krisis energy dan pangan, masyarakat tidak seharusnya jadi pasrah akan keadaan yang demikian namun perlu adanya pembinaan yang serius agar masyarakat tidak selalu berpangku tangan. 
Masyarakat membutuhkan berbagai macam binaan untuk menciptakan kesejahteraan perekonomian mereka sendiri dengan membuat kreativitas yang tinngi, pemberdayaan industri kecil masyarakat, peningkatan UMKM, dan lain sebagainya. Kesejahteraan dalam pembangunan ekonomi tidak dapat didefinisikan hanya berdasarkan konsep materialis dan hedonis, tetapi harus memasukkan tujuan-tujuan kemanusiaan dan kerohanian serta implementasi yang sangat berarti.

Tujuan-tujuan tersebut tidak hanya mencakup masalah kesejahteraan ekonomi, melainkan juga mencakup permasalahan persaudaraan manusia dan keadilan sosial ekonomi, kehidupan, kehormatan individu, masalah harta, serta keharmonisan kehidupan keluarga dan masyarakat.

Salah satu cara menguji realisasi tujuan-tujuan tersebut adalah: (1) Melihat tingkat persamaan sosial dan pemenuhan kebutuhan dasar bagi semua. (2) Terpenuhinya kesempatan untuk bekerja dan berusaha bagi semua masyarakat. (3) Terwujudnya keadilan dalam distribusi pendapatan dan kekayaan serta stabilitas ekonomi yang dicapai tanpa tingkat inflasi yang tinggi. (4) Tidak tingginya penyusutan sumber daya ekonomi yang tidak dapat diperbaharui atau ekosistem yang dapat membahayakan kehidupan.

Upaya untuk meningkatkan perekonomian masyarakat dapat diwujudkan pada beberapa langkah strategis untuk memperluas akses masyarakat pada sumber daya pembangunan serta menciptakan peluang bagi masyarakat tingkat bawah untuk berpartisipasi dalam proses pembangunan, serta masyarakat bisa mengatasi keterbelakangan dan memperkuat daya saing perekonomiannya (Sumodiningrat 1998, 146).

Selain dari pembangunannya, upaya yang bisa dilakukan oleh masyarakat untuk mencapai kesejahteraan hidup salah satunya dengan berwirausaha ataupun mendirikan industri kecil. Tujuan dari berwirausaha ini akan menciptakan masyarakat yang mandiri sehingga mampu untuk meningkatkan perekonomian masyarakat dan bisa tercapainya kesejahteraan hidup. Sedangankan pengertian industry kecil itu sendiri adala kegiatan ekonomi dilakukan oleh perorangan, rumah tangga ataupun suatu badan yang bertujuan untuk berproduksi barang maupun jasa untuk diperniagakan secara komersial dengan jumlah tenaga kerja dan modal kecil (Juara Sejati 2012). Dalam mencapai kesejahteraan ini, maka tidak lepas dari faktor-faktor yang mendukung usaha peningkatan pendapatan sumber-sumber serta sarana yang ada.

Keberadaan industri memberikan dampak atau hasil kepada perekonomian masyarakat. Secara umum dampak atau hasil tersebut antara lain menyerap tenaga kerja dan meningkatkan pendapatan masyarakat (Update Campuran 2013). Dalam surah al-Qashas ayat 77 Allah SWT berfirman menerangkan tentang kewajiban manusia untuk berusaha memperoleh kesejahteraan ekonomi, yaitu sebagai berikut:

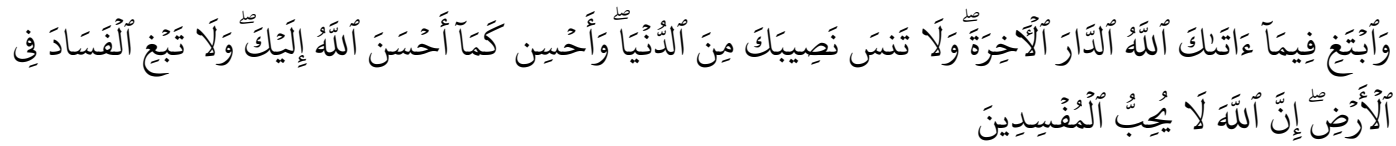

Artinya: "dan carilah pada apa yang telah anugerahkan Allah kepadamu (kebahagiaan) negeri akhirat, dan janganlah kamu melupakan bahagianmu dari (kenikmatan) duniawi dan berbuat baiklah (kepada orang lain) sebagaimana Allah telah berbuat baik, kepadamu, dan janganlah kamu berbuat kerusakan di 
(muka) bumi. Sesungguhnya Allah tidak menyukai orang-orang yang berbuat kerusakan."

Kesejahteraan hidup merupakan dambaan setiap manusia, masyarakat yang sejahtera tidak akan terwujud jika para masyarakatnya hidup dalam keadaan miskin. Oleh karena itu kemiskinan harus dihapuskan karena merupakan suatu bentuk ketidaksejahteraan yang menggambarkan suatu kondisi yang serba kurang dalam pemenuhan kebutuhan ekonomi.

Pengembangan ekonomi masyarakat dapat dilihat dari tiga segi, yaitu: (1) Menciptakan suasana atau iklim yang memungkinkan potensi masyarakat berkembang. Titik tolak pemikirannya adalah pengenalan bahwa setiap manusia memiliki potensi yang dapat dikembangkan, tidak ada masyarakat yang sama sekali tanpa daya. (2) Memperkuat potensi ekonomi yang dimiliki oleh masyarakat itu. Dalam rangka memperkuat potensi ekonomi masyarakat ini upaya yang amat pokok adalah peningkatan taraf pendidikan dan derajat kesehatan, serta terbukanya kesempatan untuk memanfaatkan peluang-peluang ekonomi. (3) Mengembangkan ekonomi masyarakat juga mengandung arti melindungi masyarakat dan mencegah terjadinya persaingan yang tidak seimbang, serta mencegah eksploitasi golongan ekonomi yang kuat atau yang lemah. Upaya melindungi masyarakat tersebut tetap dalam rangka proses pemberdayaan dan pengembangan masyarakat.

\section{METODE PENELITIAN}

Teknik pengumpulan data yang dilakukan adalah wawancara, dokumentasi, kuisioner dan studi kepustakaan. Teknik analisa data yang digunakan adalah teknik analisis data kuantitatif dengan menggunakan SPSS correlation dimana teknik ini berusaha menyimpulkan data yang berhubungan dengan objek penelitian secara keseluruhan sesuai dengan tujuab penelitian yang sudah ditentukan dengan menggunakan rumus yang berlaku seperti uji validitas data, uji asumsi klasik dan uji analisis data. Kuisioner dibagikan kepada 174 orang responden yaitu nasabah yang meminjam modal di USP Penebal Teguh Mandiri Desa Penebal.

\section{HASIL DAN PEMBAHASAN PENELITIAN}

\section{Bentuk Transaksi Unit Simpan Pinjam Penebal Teguh Mandiri Desa Penebal}

Bentuk transaksi yang dilakukan oleh pemanfaat modal Unit Simpan Pinjam adalah pemabayaran tunai secara langsung kepada pihak USP dan ada juga sebagian masyarakat yang melakukan transfer ke rekening USP karena mereka sudah memiliki rekening sendiri. Tetapi kebanyakan masyarakat melakukan transaksi tunai atau pembayaran tunai ke pada pihak USP Penebal Teguh Mandiri.

Pembayaran angsuran dilakukan di Kantor USP pada hari kerja dengan menandatangani bukti pembayaran di buku monitoring pemanfaat dan dokumen lain yang telah disiapkan oleh Unit Simpan Pinjam, kemudian jika dilakukan pelunasan sebelum batas waktu yang telah ditetapkan, maka pemanfaat diwajibkan membayar seluruh sisa pokok pinjaman dan ditambah jasa pinjaman sampai pada bulan saat dilakukan pelunasan. Jasa pinjaman diberikan maksimal $10 \%$ pertahun atau 0,84 perbulan dari jumlah pinjaman dan penetapannya 
dilakukan melalui rapat kepengurusan BUM Desa, khusus pinjaman masyarakat miskin dibebankan jasa maksimal $6 \%$ pertahun dan penetapannya dilakukan melalui rapat kepengurusan BUM Desa. Tetapi pihak USP belum ada menyalurkan dana untuk masyarakat misikin karena rata-rata masyarakat Desa Penebal dikategorikan masyarakat yang masih standar.

\section{Pengaruh Unit Simpan Pinjam (USP) Penebal Teguh Mandiri Terhadap Peningkatan Kesejahteraan Ekonomi Desa Penebal}

Peningkatan Kesejahteraan Ekonomi Adalah suatu usaha yang dilakukan oleh masyarakat untuk mendapatkan keuntungan benda dalam melakukan pemenuhan kebutuhannya. Tingkat kesejahteraan masyarakat dapat diukur dari: (a) Tingkat pendapatan, (b) Sisi terpenuhi kebutuhan.

Masyarakat yang meminjam modal dari USP sangat membantu perekonomiannya apalagi dari segi pendapatan. Karena, sebelum masyarakat meminjam modal dari USP pendapatannya sekitar 1.000 .000 ,- perbulan, tetapi sekarang sudah mencapai 2.000.000,- sampai 3.000.000,- perbulan dengan membuat usaha dari pinjaman modal USP tersebut. Kemudian dari sisi terpenuhi kebutuhan, ada sebagian masyarakat yang mengatakan bahwa dengan adanya USP ini sangat membantu kebutuhannya. Contohnya dari segi pembangunan, masyarakat yang memiliki usaha yang dulunya kecil dengan adanya modal dari USP sekarang usahanya sudah besar.

Pengaruh Unit Simpan Pinjam (USP) Terhadap Peningkatan Kesejahteraan Ekonomi Masyarakat dapat dilihat pada uji-uji yang telah dilakukan peneliti dengan bantuan software SPSS, dengan hasil sebagai berikut: (1) Berdasarkan hasil uji normalitas menggunakan angka residual yang dilakukan peneliti dalam penelitiannya untuk kuesioner yaitu semua pernyataan normal dengan nilai signifikan $0.140>0.05$, karena nilai signifikan > 0.05 maka Ha diterima (normal). (2) Berdasarkan hasil uji regresi linier sederhana yang peneliti lakukan dapat disimpulkan bahwa, anatar variabel (X) Unit Simpan Pinjam (USP) dan variabel (Y) Peningkatan Kesejahteraan Ekonomi Masyarakat memiliki pengaruh yang signifikan dengan angka signifikan $<0.05$ yaitu $0.000<0.05$. karena berdasarkan hipotesis, jika nilai signifikan $<0.005$ maka dinyatakan berpengaruh (Ha diterima). (3) Berdasarkan uji determinasi $\left(\mathrm{R}^{2}\right)$ diketahui $\mathrm{R}$ square sebesar 0.380 angka tersebut disebut juga sebagai koefisien determinasi. Besarnya angka 0.380 sama dengan 38\%, artinya 38\% variabel Unit Simpan Pinjam mempengaruhi variabel Peningkatan Kesejahteraan Ekonomi Masyarakat. Sementara sisanya dari $(100 \%-38 \%)$ yaitu $62 \%$ Peningkatan Kesejahteraan Ekonomi Masyarakat dipengaruhi oleh variabel lain yang tidak dimasukkan dalam model penelitian ini. (4) Berdasarkan hasil hipotesis yang dilakukan, maka dapat disimpulkan bahwa Unit Simpan Pinjam berpengaruh terhadap Peningkatan Kesejahteraan Ekonomi Masyarakat terbukti. Hal ini dapat ditunjukkan dengan nilai signifikan sebesar 0.000 yang lebih kecil dari 0.05 serta nilai koefisien regresi 0.239 maka dapat disimpulkan bahwa Unit Simpan Pinjam (USP) memberikan kontribusi dalam meningkatkan ekonomi masyarakat Desa Penebal.

Untuk menguji hipotesis penelitian ini, digunakan teknik regression. Uji ini digunakan untuk menguji hipotesis yang meliputi: melihat pengaruh antara Unit Simpan Pinjam (USP) terhadap Peningkatan Kesejahteraan Ekonomi Masyarakat. Berdasarkan uji regresi untuk hipotesis yang peneliti lakukan, 
terdapat pengaruh yang signifikan antara Unit Simpan Pinjam (USP) Terhadap Peningkatan Kesejahteraan Ekonomi Masyarakat dengan nilai signifikannya 0.000 $<0.05$. Hal ini karena, untuk uji regresi jika nilai signifikannya $<$ dari 0.05 maka uji tersebut dinyatakan memiliki pengaruh (Ha diterima). Namun jika nilai signifikannya > dari 0.05 maka uji tersebut dinyatakan tidak berpengaruh (Ho ditolak).

\section{KESIMPULAN}

Unit simpan pinjam salah satu program pemberdayaan desa yang bergerak dibidang keuangan untuk menunjang usaha ekonomi produktif didesa yang bersangkutan. Bentuk transaksi unit simpan pinjam Penebal Teguh Mandiri adalah dengan cara melakukan transaksi tunai kepada pihak unit simpan pinjam sehingga memberikan kemudahan bagi masyarakat dalam membayar pinjaman. Namun ternyata unit simpan pinjam tidak sepenuhnya memberi kontribusi dalam peningkatan kesejahteraan ekonomi masyarakat karena tingkat pengaruhnya hanya 38\%. Hal ini membuktikan bahwa tingkat kesejahteraan ekonomi masyarakat tidak hanya dipengaruhi oleh unit simpan pinjam tetapi masih banyak faktor lain yang mempengaruhi tingkat kesejahteraannya. Untuk itu peneliti menyarankan ada penelitian lanjutan untuk meneliti faktor-faktor lain tersebut.

\section{DAFTAR PUSTAKA}

Anshori, Syaifudin Endang. 1993. Wawasan Islam Pokok-Pokok Pikiran Islam dan Umatnya. Jakarta: Raja Grafindo.

Badan Pusat Statistik Kabupaten Bengkalis. 2018. Luas Wilayah Kabupaten Bengkalis Menurut Kecamatan. Di akses dari halaman web: https://bengkaliskab.bps.go.id/ pada tanggal 17 Juli 2018.

Bupati Bengkalis. 2014. Peraturan Bupati Bengkalis No 38 Tahun 2014 Tentang Petunujuk Teknis Program Keberdayaan Masyarakat Perdesaan (PPKMP) Kabupaten Bengkalis.

Bupati Bengkalis. 2017. Peraturan Bupati Bengkalis No 71 Tahun 2017 Tentang Pedoman Penyertaan Modal Desa Ke Badan Usaha Milik Desa Yang Berasal Dari Dana Usaha Ekonomi Desa.

Dhani, Ilham. 2018. "Pengaruh Usaha Ekonomi Desa Simpan Pinjam (UED-SP) Terhadap Peningkatan Pendapatan Masyarakat Desa Teluk Latak Dalam Perspektif Islam”. Skripsi STIE Syariah Bengkalis.

Darwis, Amri. 2015. Metode Penelitian Pendidikan Islam. Pekanbaru: Suska Press.

Departemen Pendidikan dan Kebudayaan. 1988. Kamus Besar Bahsa Indonesia. Jakarta.

Disperindag. 1997. Keputusan Menteri Perindustrian dan Perdagangan Republik Indonesia. Pekanbaru.

Ghozali, Imam. 2006. Aplikasi Analisis Multivariate SPPS. Semarang: Badan Penerbit Universitas Diponogoro.

Irianto, Agus. 2004. Statistik: Konsep Dasar, Aplikasi dan Pengembangannya. Jakarta: Kencana Prenada Group. 
Juara Sejati. 2012. Makalah Pengantar Industri Kecil. Diakses dari halaman web: http://djanksoleh.blogspot.com/2012/11/makalah-pengantar-industrikecil.html, tanggal 20 Juli 2018.

Kasmir dan Jakfar. 2003. Studi Kelayakan Bisnis. Jakarta: Kencana.

Kementerian Dalam Negeri. 1998. Peraturan Mentri Dalam Negri Nomor 6 Tahun 1998 Tentang Usaha Ekonomi Desa Simpan Pinjam (UED-SP).

Kurniawan, Albert. 2009. Belajar Mudah SPSS Untuk Pemula. Yogyakarta: Mediacom.

Kurniawati, Dwi Pratiwi; Bambang Supriyono dan Imam Hanafi. 2013. "Pemberdayaan Masyarakat di Bidang Usaha Ekonomi (Studi Pada Badan Pemberdayaan Masyarakat Kota Mojokerto)". Jurnal Administrasi Publik (JAP) 1 (4), 9-14.

Londa, Very Y. 2014. "Peningkatan Pendapatan Masyarakat Melalui Pemberdayaan Desa". Jurnal LPPM Bidang Ekososbudkum Universitas Sam Ratulangi 1 (1).

Mubyarto. 1997. Ekonomi Rakyat, Program IDT dan Demokrasi Ekonomi Indonesia. Jakarta: Aditya.

Nailufarh, Qurratul A'yun. 2010. "Kesejahteraan Ekonomi Rakyat” Jurnal Balance Economics, Management and Accounting, Nomor 8.

Natanael, Sufren Yonathan. 2014. Belajar Otodidak SPSS Pasti Bisa. Jakarta: PT. Elex Media Komputindo.

Noor, Juliansyah. 2012. Metodologi Penelitian: Skripsi, Tesis,Disertasi dan Karya Ilmiah. Jakarta: Kencana.

Nurhanafi, Anis. 2014. "Sistem Informasi Simpan Pinjam Pada Koperasi Sari Mulyono Kecamatan Ngadirojo". Indonesian Journal on Networking and Security 3 (3).

Prasetyo, Dwi Yuli. 2018. "UED-SP Lancang Kuning Desa Rumbai Jaya Kecamatan Kempas". Jurnal Teknik Industri UNISI 2 (1).

Riduwan. 2010. Metode dan Teknik Menyusun Tesis. Bandung: Alfabeta.

Republik Indonesia. 2008. Undang-Undang Republik Indonesia Nomor 20 Tahun 2008 Tentang Usaha Mikro, Kecil Dan Menengah.

Singarimbun dan Effendi. 1998. Metode Peneliti Survey. Jakarta: Pustaka LP3ES.

Siregar, Syofian. 2012. Statistik Deskriptif Untuk Penelitian. Jakarta: Rajawali Pers.

Solihin, Ismail. 2006. Pengantar Bisnis, Pengenalan Peraktis Dan Studi Kasus, Jakarta: Kencana.

Sudjana. 2004. Pendidikan Nonformal: Wawasan, Sejarah Perkembangan, Filsafat dan Teori Pendukung Serta Asas. Bandung: Falah Production.

Sugiyono. 2005. Metodologi Penelitian Bisnis. Bandung: Alfabeta.

Sugiyono. 2017. Statistika Untuk Penelitian. Bandung: Alfabeta.

Sujarweni, V. Wiratna. 2015. Statistik Untuk Bisnis Dan Ekonomi. Yogyakarta: Pustaka Baru Press.

Sumodiningrat, Gunawan. 1998. Membangun Perekonomian Rakyat. Yogyakarta: IDEA.

Trenggonowati. 2009. Metodologi Penelitian Ekonomi Dan Bisnis. Yogyakarta: BPFE.

Update Campuran. 2013. Pengertian Industri dan Dampak Pembangunan Industri. Diakses dari halaman web: 
http://updatecampuran.blogspot.com/2013/08/pengertian-industri-dandampak.html, tanggal 25 Juli 2018.

Usman, Husaini dan Purnomo Setiady Akbar. 2006. Pengantar Statistika. Jakarta: Bumi Aksara. 